\title{
Presence of tropical hydrophytes in relation to limnological para- meters - a study of two freshwater ponds in Kolkata, India
}

\author{
G. Mukhopadhyay, A. Dewanji* \\ Agricultural and Ecological Research Unit, Indian Statistical Institute, 203 B.T. Road, Kolkata - 700 108, India.
}

\begin{abstract}
The presence of different species of hydrophytes was investigated in relation to Secchi disk visibility, $\mathrm{pH}$, dissolved oxygen, electrical conductivity, total Kjeldahl nitrogen, total phosphorus and chlorophyll- $a$ concentration in two tropical ponds nearby Kolkata, India, during a three years period (June 1999 to May 2002). The dominant flora in the ponds namely, Alternanthera philoxeroides, Nymphoides hydrophylla, Lemna aequinoctialis, and Vallisneria spiralis were found to subsist over a wide amplitude of nutrient levels thereby showing their adaptability to highly eutrophic ecosystems, a common feature of the tropics. However, the presence of some minor species could be associated with a narrow range of specific limnological variables.
\end{abstract}

Keywords : Hydrophytes, nitrogen, phosphorus, minor flora, tropical ponds.

\section{Introduction}

The presence of different species of hydrophytes at a given site is a multifactorial ecological question to evaluate, although the influence of limnological parameters as one of the functional environmental factors for species occurrence has received great attention (Moyle 1945, Hutchinson 1975, Catling et al. 1986). Many studies have correlated the distribution of different aquatic macrophytes with water chemistry in lakes (Spence 1967, James et al. 2005) and running waters (Whitton 1979, Schneider \& Melzer 2003). Several limnological parameters were found to be responsible for the distribution pattern of hydrophytes, such as $\mathrm{pH}$ (Palmer et al. 1992), alkalinity (Vestergaard \& SandJensen 2000), conductivity (Mäkelä et al. 2004) and nutrients (Heegard et al. 2001) but most observations have been restricted to temperate regions during the peak growth period of aquatic vegetation.

Ponds, habitats for a variety of aquatic flora (Cook 1996), are a major wet biotope in tropical landscapes.

\footnotetext{
* Corresponding author :

E-mail: anjana@isical.ac.in
}

Sri Lanka has over 12000 ponds representing an estimated area of 175774 ha (Baldwin 1991) while 67\% of the 14000 lentic water bodies in Mexico are ponds (López-Blanco \& Zambrano 2002). About 210000 ponds are distributed throughout Japan (Shimoda \& Abe 2001) while China has 86825 ponds, comprising a total storage capacity of 413 billion $\mathrm{m}^{3}$ (Xiangcan 2003). Bangladesh has about 1.3 million ponds which cover $1.13 \%$ of its area (FRSS 1986), while in India ponds constitute about $3 \times 10^{6}$ ha of the 7 million ha of total inland water resources (GOI 2005). These waterbodies are an integral component of the daily life activities of rural people for their subsistence and thereby tropical ecosystems are more vulnerable to eutrophication due to their rampant anthropogenic use. Therefore, regular monitoring of limnological parameters, using inexpensive methods, are much needed.

Aquatic plants grow profusely in the tropics and many of them are also used for subsistence of human livelihood support by several thousands of rural families in developing countries (Gichuki et al. 2001, Ghosh 2005). Since the response of individual plant species is known to be related to the variation in environmental factors, the presence/absence of hydrophytes, which could easily be monitored by visual inspection, could 
be used to indicate the effects of limnological changes. Due to mild winters in tropical regions, plants grow throughout the year thus, annual data is necessary to understand habitat tolerance and preference limit of individual species. There is a paucity of data on the occurrence of different plant species in relation to the water quality in tropical ponds (Mukhopadhyay \& Dewanji 2002) although there are reports of independent studies of aquatic plants (Tripathi et al. 1991) as well as of water quality in relation to the growth of phytoplanktons (Bhaskaran et al. 1991). This data could also be valuable in respect to botanical conservation (Angélibert et al. 2004).

Due to lack of historical data, the present survey was initiated in two freshwater ponds over a period of three years in order to collect baseline data with the aim of finding whether the presence/absence of different species of hydrophytes had any influence on the limnological parameters of water bodies in which they grow.

\section{Material and methods}

\section{Study site}

Two ponds, located within the Institute campus in Baranagar, Kolkata, India $\left(22^{\circ} 20^{\prime}-22^{\circ} 40^{\prime} \mathrm{N}\right.$ latitude and $88^{\circ} 10^{\prime}-88^{\circ} 40^{\prime}$ E longitude) were selected for the investigation. Both ponds were small ( $<1 \mathrm{ha})$ and shallow $(\leq 5 \mathrm{~m})$ as detailed in Mukhopadhyay et al (2004b). The ponds were located close to each other and were primarily used by the local people for bathing and washing of clothes. The climate was typically a tropical monsoon type with normal annual rainfall of $160 \mathrm{~cm}$ and water temperature ranging from $18^{\circ} \mathrm{C}$ to $34^{\circ} \mathrm{C}$.

\section{Limnological parameters}

Ponds were sampled monthly between $09 \mathrm{~h} 00$ and $10 \mathrm{~h} 30$ using an inflatable boat for a period of three years (June 1999 to May 2002). Water samples were collected from four randomly selected points from each pond at $1 \mathrm{~m}$ below surface, with the help of a Van Dorn horizontal bottle sampler. The total number of observation was, thus, $(n)=288$ [ 2 ponds ( 4 sampling points) 36 months]. In order to study the interaction between plants and their ambient water, all sampling points were located along the littoral zone, where vegetation was observed. Underwater light visibility was recorded using a Secchi disk according to Welch (1952). In-situ measurements of $\mathrm{pH}$, dissolved oxygen and electrical conductivity were taken using a multiparameter calibrated probe attached to a WQC-20A water quality checker, manufactured by Xebex Inter- national Ltd., Tokyo, Japan. Total nitrogen was measured by the macro Kjeldahl method. Total phosphorus was determined by the ascorbic acid method. Chlorophyll- $a$ concentration was measured spectrophotometrically following pigment extraction with $90 \%$ acetone. Values were corrected for phaeophytin interference. Standard methods were followed for all chemical and biological parameters (APHA 1998).

\section{Hydrophytes}

Different species of hydrophytes were recorded on a monthly basis from June 1999 to May 2002, from four randomly selected sampling stations by walking along the margin of each pond near the littoral zone as well as from the boat (used for water sampling). Each sampling station was a stretch of about $40 \mathrm{~m}$. An aquascope and a rake were used for observation and collection of submerged plants (Dennis \& Isom 1984). Formation of dense vegetation bed along with flowering of each species was also observed. All collected plants were kept in plastic bags and transported to the laboratory where they were washed thoroughly to remove silt, snails, epiphytes and other unwanted materials. The excess water was then drained off and healthy specimens were sorted and pressed for the preparation of herbarium. Voucher specimens of different species were kept in the laboratory. Identification was followed according to Cook (1996).

\section{Statistical analysis}

Univariate description of individual limnological variables based on calculation of sample statistics such as mean, SD, maximum and minimum values have been done on pooled dataset of two ponds. An attempt was made to determine whether the presence/absence of a plant species can be associated with changes in each of the limnological parameters. The data was classified into two groups based on the presence or absence of a particular plant species for each data point. A oneway analysis of variance (ANOVA) was carried out separately for each case. Comparisons were made between mean values of each limnological variable during the period of presence versus the period of absence of each plant. The BMDP $4 \mathrm{~V}$ program (Dixon 1992) run on Sun Solaris Operating System (Version 9) was used for this purpose.

\section{Results}

\section{Limnological parameters}

Summary statistics of limnological parameters (June 
1999 to May 2002) is reported in Table 1. Secchi disk visibility ranged from 0.7 to $3.6 \mathrm{~m}$. $\mathrm{pH}$ values showed little variation in comparison to other water quality variables. Dissolved oxygen concentration fluctuated between 0.45 to $4.79 \mathrm{mgl}^{-1}$ during the study period. Electrical conductivity values ranged from 71 to 145 $\mathrm{mSm}^{-1}$. Total Kjeldahl nitrogen as well as chlorophyll$a$ concentrations were characterized by wide fluctuations. Total phosphorus content varied from 0.02 to $2.06 \mathrm{mgl}^{-1}$.

\section{Hydrophytes}

The species list of hydrophytes along with their growth forms and occurrence is given in Table 2. All types of growth forms was found in this study. The four dominant species (occurrence $\geq 50 \%$ ) were Alternanthera philoxeroides (Martius) Griseb, Lemna aequinoctialis Welwitsch, Nymphoides hydrophylla (Loureiro) O. Kuntze and Vallisneria spiralis L. The minor species (occurrence : 10 - 30\%) were Azolla pinnata R. Brown, Cladophora glomerata (L.) Kütz, Commelina benghalensis L., Eclipta alba (L.) Hasskarl, Marsilea minuta L., Nymphaea pubescens Willd, Rotala rotundifolia Koehne. Hydrodictyon reticulatum (L.) Largerheim Makino and Trapa natans L. var bispinosa (Roxb.) were the two species with occurrence $<$ $5 \%$.

Except for $N$. hydrophylla, the other dominant flora produced dense stands. In case of minor flora, A. pinnata and $H$. reticulatum were the only two plants which

Table 1. Mean, SD, minimum and maximum values of limnological parameters of two ponds (pooled dataset).

\begin{tabular}{lccc}
\hline Water quality parameter & Mean $\pm \mathrm{SD}$ & Minimum & Maximum \\
\hline $\begin{array}{l}\text { Physical } \\
\text { Secchi disk visibility (m) }\end{array}$ & $1.6 \pm 0.51$ & 0.7 & 3.6 \\
Chemical & & & \\
$\mathrm{pH}$ & $7.3 \pm 0.26$ & 6.6 & 8.4 \\
Dissolved oxygen $\left(\mathrm{mg} \mathrm{l}^{-1}\right)$ & $2.38 \pm 1.22$ & 0.45 & 4.79 \\
Electrical conductivity $\left(\mathrm{mS} \mathrm{m}^{-1}\right)$ & $102.7 \pm 12.35$ & 71.0 & 145.3 \\
Nutrient & & & \\
Total Kjeldahl nitrogen $\left(\mathrm{mg}^{-1}\right)$ & $5.87 \pm 6.30$ & 0.0 & 30.85 \\
$\quad$ Total phosphorus $\left(\mathrm{mg} \mathrm{l}^{-1}\right)$ & $0.58 \pm 0.35$ & 0.02 & 2.06 \\
Biological & & & \\
$\quad$ Chlorophyll- $a\left(\mathrm{mg} \mathrm{m}^{-3}\right)$ & $2.56 \pm 3.58$ & 0.0 & 27.64 \\
\hline
\end{tabular}

were able to grow rapidly to dense proportions. Nearly half of the total species showed only their vegetative phase in this limnological condition of which L. aequinoctialis was the only dominant species exhibiting this phase.

\section{Presence/absence of hydrophytes}

Table 3 shows the differences in limnological parameters during periods of presence and absence of individual species. Significant differences between the period of presence and absence of $V$. spiralis was evident for all limnological parameters. Next was T. natans, which showed significant difference for five out of seven limnological variables. $C$. glomerata and $L$. aequinoctialis was at the other extreme showing significant difference for only one variable i.e. electrical conductivity and total phosphorus respectively.

For each of the plants that showed significant differences in mean value of a particular limnological variable, maximum and minimum values during their periods of presence were next plotted for that limnological variable and the results are shown in Figure 1. The first appearance/record of the plant has also been shown in the figures as a point on the "presence line". It can be seen that four species namely $M$. minuta, $N$. hydrophylla, $V$. spiralis and $R$. rotundifolia were found

Table 2. Species list, growth form and occurrence of hydrophytes in two ponds. The names of plants in bold indicate both vegetative and reproductive phases. The others were present only in their vegetative phase. Occurrence (n) in bold shows the ability of the plants to rapidly form dense bed. *: at each point, based on $\mathrm{n}=$ 288.

\begin{tabular}{llrr}
\hline \multirow{2}{*}{ Species name } & Growth form & \multicolumn{2}{c}{ Occurrence* } \\
\cline { 3 - 4 } Alternanthera philoxeroides & Emergent & $\mathbf{n}$ & $\%$ \\
\cline { 2 - 4 } Azolla pinnata & Free-floating & $\mathbf{1 6 4}$ & 57 \\
Cladophora glomerata & Submerged & 28 & 11 \\
Commelina benghalensis & Emergent & 48 & 17 \\
Eclipta alba & Emergent & 52 & 18 \\
Hydrodictyon reticulatum & Submerged & $\mathbf{4}$ & 1 \\
Lemna aequinoctialis & Free-floating & $\mathbf{2 1 2}$ & 74 \\
Marsilea minuta & Emergent & 72 & 25 \\
Nymphaea pubescens & Rooted with floating-leaves & 80 & 28 \\
Nymphoides hydrophylla & Rooted with floating-leaves & 224 & 78 \\
Rotala rotundifolia & Submerged & 56 & 19 \\
Trapa natans var bispinosa & Rooted with floating-leaves & 12 & 4 \\
Vallisneria spiralis & Submerged & $\mathbf{1 4 4}$ & 50 \\
& & & \\
\hline
\end{tabular}


Table 3. Differences in limnological parameters (mean value) for presence (+) and absence (-) of plant species (bold values show significance at 0.05 level).

\begin{tabular}{|c|c|c|c|c|c|c|c|c|c|c|c|c|c|c|}
\hline \multirow[t]{2}{*}{ Plant } & \multicolumn{2}{|c|}{$\begin{array}{l}\text { Secchi disk } \\
\text { visibility }\end{array}$} & \multicolumn{2}{|c|}{$\mathrm{pH}$} & \multicolumn{2}{|c|}{$\begin{array}{c}\text { Dissolved } \\
\text { oxygen }\end{array}$} & \multicolumn{2}{|c|}{$\begin{array}{c}\text { Electrical } \\
\text { conductivity }\end{array}$} & \multicolumn{2}{|c|}{$\begin{array}{l}\text { Total Kjeldahl } \\
\text { nitrogen }\end{array}$} & \multicolumn{2}{|c|}{$\begin{array}{c}\text { Total } \\
\text { phosphorus }\end{array}$} & \multicolumn{2}{|c|}{ Chlorophyll- $a$} \\
\hline & + & - & + & - & + & - & + & - & + & - & + & - & + & - \\
\hline A. philoxeroides & 1.62 & 1.58 & 7.34 & 7.31 & 2.11 & 2.74 & 98.03 & 108.94 & 6.12 & 5.53 & 0.61 & 0.54 & 2.08 & 3.19 \\
\hline A. pinnata & 1.56 & 1.61 & 7.22 & 7.34 & 2.31 & 2.39 & 110.03 & 101.82 & 6.12 & 5.53 & 0.38 & 0.60 & 2.08 & 2.53 \\
\hline C. glomerata & 1.73 & 1.59 & 7.29 & 7.33 & 2.56 & 2.36 & 108.39 & 102.12 & 4.26 & 6.04 & 0.48 & 0.59 & 3.23 & 2.49 \\
\hline C. benghalensis & 1.72 & 1.58 & 7.54 & 7.28 & 2.16 & 2.43 & 100.41 & 103.20 & 5.78 & 5.78 & 0.45 & 0.60 & 1.39 & 2.80 \\
\hline E. alba & 1.72 & 1.58 & 7.35 & 7.32 & 1.91 & 2.48 & 96.83 & 104.03 & 6.00 & 5.84 & 0.60 & 0.58 & 1.02 & 2.90 \\
\hline H. reticulatum & 1.46 & 1.60 & 7.71 & 7.32 & 4.16 & 2.36 & 104.82 & 102.70 & 1.98 & 5.92 & 0.34 & 0.58 & 2.55 & 2.56 \\
\hline L. aequinoctialis & 1.60 & 1.59 & 7.34 & 7.28 & 2.33 & 2.52 & 102.29 & 103.96 & 6.07 & 5.29 & 0.62 & 0.47 & 2.79 & 1.93 \\
\hline M. minuta & 1.70 & 1.57 & 7.43 & 7.29 & 2.33 & 2.40 & 101.04 & 103.30 & 8.12 & 5.12 & 0.58 & 0.58 & 1.18 & 3.02 \\
\hline N. pubescens & 1.66 & 1.58 & 7.39 & 7.30 & 2.40 & 2.38 & 100.46 & 103.60 & 6.58 & 5.59 & 0.66 & 0.55 & 2.61 & 2.54 \\
\hline N. hydrophylla & 1.64 & 1.46 & 7.36 & 7.21 & 2.44 & 2.16 & 102,94 & 102.00 & 6.09 & 5.09 & 0.56 & 0.65 & 2.08 & 4.26 \\
\hline R. rotundifolia & 1.76 & 1.56 & 7.31 & 7.33 & 2.06 & 2.46 & 102.81 & 102.71 & 6.89 & 5.62 & 0.55 & 0.59 & 1.16 & 2.90 \\
\hline T. natans & 1.61 & 1.60 & 7.87 & 7.30 & 4.07 & 2.31 & 98.48 & 102.92 & 11.76 & 5.61 & 0.21 & 0.60 & 0.36 & 2.66 \\
\hline V. spiralis & 1.67 & 1.54 & 7.41 & 7.24 & 2.67 & 2.09 & 104.17 & 101.29 & 6.84 & 4.89 & 0.53 & 0.63 & 1.94 & 3.89 \\
\hline
\end{tabular}

to grow in wide range of transparency values $(0.7$ to $3.2 \mathrm{~m}$, Figure 1a). The presence of $A$. philoxeroides, $C$. benghalensis, $H$. reticulatum, M. minuta, N. pubescens, N. hydrophylla, T. natans and V. spiralis indicated circum-neutral to alkaline $\mathrm{pH}$ (Figure 1b). The narrow range ( 7.5 to 7.8 ) exhibited by $H$. reticulatum could be due to its small sample size. The presence of $H$. reticulatum and $T$. natans (both species with low occurrence) indicated relatively narrow dissolved oxygen levels ranging from 3.7 to $4.6 \mathrm{mg} \mathrm{l}^{-1}$ (Figure 1c). C. glomerata was the only species that preferred to grow in waters with a narrow conductivity band (103 to $118 \mathrm{mS} \mathrm{m}^{-1}$, Figure $\left.1 \mathrm{~d}\right)$. It can be seen that presence of T. natans was restricted to a very narrow but high total Kjeldahl nitrogen band ranging from 10 to $13 \mathrm{mg} \mathrm{l}^{-1}$ (Figure 1e) along with total phosphorus $(0.07$ to 0.36 $\left.\mathrm{mg}^{-1}\right)$ and chlorophyll- $a$ ( 0 to $0.7 \mathrm{mg} \mathrm{m}^{-3}$ ) as is evident from Figure $1 \mathrm{f}$ and $\mathrm{g}$. The presence of $E$. alba also showed preference for low chlorophyll- $a$ values $(0$ to $4.7 \mathrm{mg} \mathrm{m}^{-3}$, Figure $1 \mathrm{~g}$ ). Excepting for A. philoxeroides and $N$. hydrophylla which were found to be present over a wide range of chlorophyll- $a$ values ( 0 to 22 $\mathrm{mg} \mathrm{m}^{-3}$ ), all the other six species existed at chlorophyll- $a$ concentrations $\leq 12 \mathrm{mg} \mathrm{m}^{-3}$.

\section{Discussion}

Literature reports on monthly variability in species number, or occurrence of individual species in relation to the limnological parameters of tropical ponds, are scarce. However, the nature of occurrence of diverse aquatic plant species in tropical and subtropical ponds have been found to show a certain degree of interassociation based on their growth forms. The most common association was the formation of pure bed/ mixture of two to three species of invasive free-floating plants (Munawar 1970, Rai \& Dutta Munshi 1979, Philipose et al. 1970, Varshney \& Singh 1976) with one to three species of emergent vegetation (Khondker \& Kabir 1995, Ghosh et al. 1993, Ghosh 2005). The other type was the occurrence of mixed communities of submerged flora (two to three species) together with floating-leaved (one to two species) and emergent (one to four species) forms (Philipose et al. 1970, Gopal 1990). As found in this study, the mixed occurrence of all growth forms has also been widely reported in other tropical and subtropical ponds (Kunii \& Maeda 1982, Gopal \& Chamanlal 1991, Hussainy 1965, Nasar \& Dutta Munshi 1974, Pandey et al. 1988, Kunii 1991, Zambrano et al. 1999). 


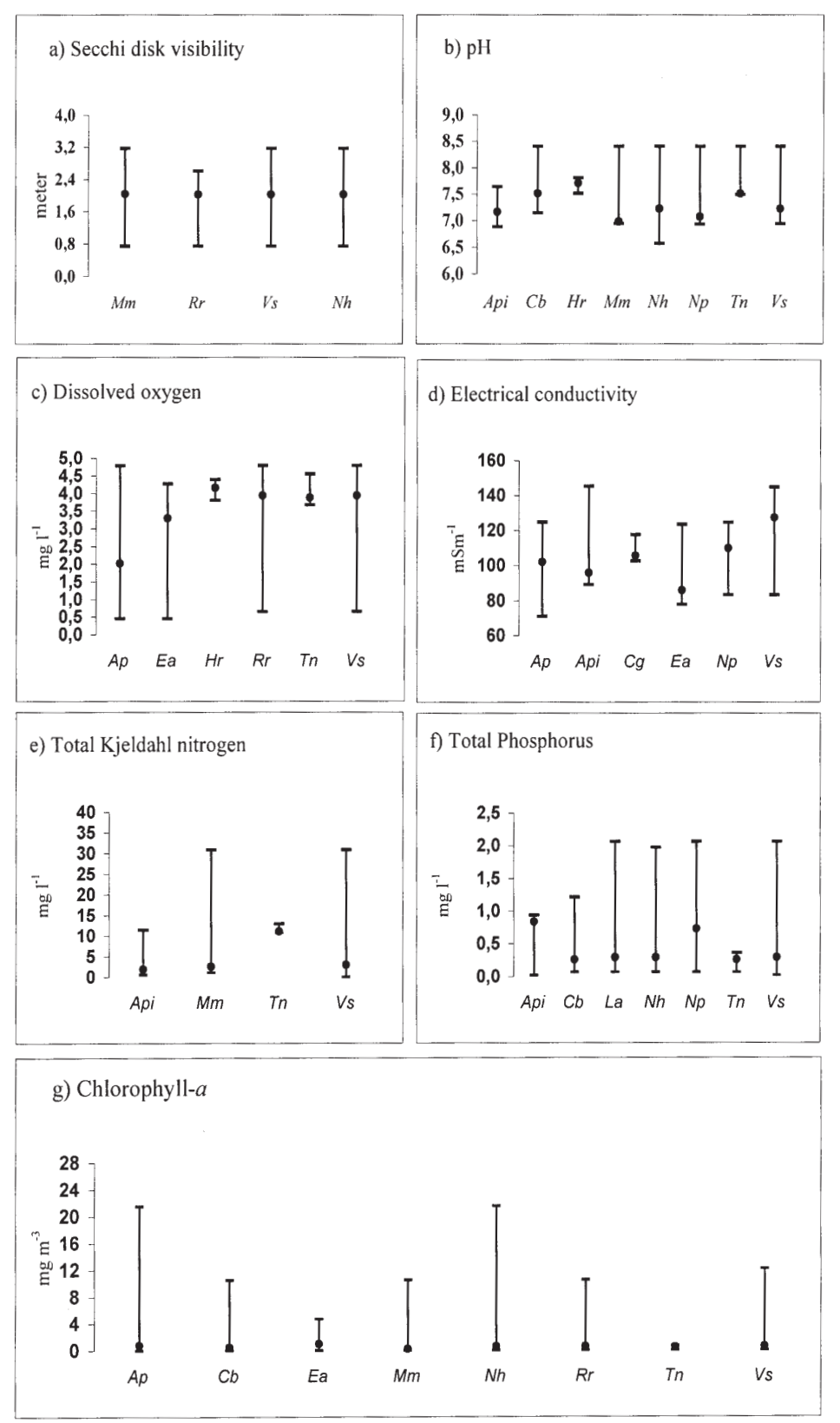

Fig.1. Range values of limnological parameters of selected species during their period of presence (Ap=A. philoxeroides, Api=A. pinnata, $C g=C$. glomerata, $C b=C$. benghalensis, Ea $=E$. alba, $H r=H$. reticulatum, La $=$ L. aequinoctialis, Mm $=M$. minuta, Np=N. pubescens, Nh=N. hydrophylla, $R r=R$. rotundifolia, $T n=T$. natans, $V s=V$. spiralis).

Regarding the limnological parameters - the Secchi disk visibility, electrical conductivity, total Kjeldahl nitrogen and total phosphorus concentration as found in this study were found to be higher when compared to other ponds having all growth forms of aquatic plants. However, the dissolved oxygen contents were similar. Low dissolved oxygen values ranging from 0 to $1.5 \mathrm{mg} \mathrm{l}^{-1}$ have been reported in ponds, which have a predominance of the free-floating varieties (Munawar 1970, Rai \& Dutta Munshi 1979). Maximum level 
of chlorophyll- $a$ was found to be similar to another subtropical pond with emergent species (Khondker \& Kabir 1995) while the value was much lower when compared to a subtropical pond with all growth forms (Kunii \& Maeda 1982). In turbid tropical ponds without aquatic vegetation wide fluctuations in chlorophyll- $a$ values have been reported (Jana \& Kundu 1993).

\section{Presence/absence of hydrophytes}

Each species of aquatic macrophytes is known to have its own chemical tolerance thus charting the presence/absence data of individual species is important in understanding its ecology, adaptability and phytosociology (Seddon 1972, Kadono 1982).

Secchi disk visibility - The wide range of Secchi disk visibility values observed for $V$. spiralis (Figure 1a) was similar to that reported by Kunii \& Maeda (1982) for a subtropical pond with the same species as well as rich in other growth forms of aquatic vegetation. Thus tolerance of this species in low light is evident. Charophytes have also been reported to be associated with high Secchi disk visibility in temperate ponds (Crawford 1977) as well as in shallow lakes of sub-tropical regions (Steinman et al. 2002).

$p H$ - The present study shows the association of a number of plant species to circum neutral to alkaline pH (Figure 1b). Friday (1987) reported indicator plants for low $\mathrm{pH}(<7)$ in acidic ponds. Adaptation of plants to the tolerance of alkaline $\mathrm{pH}$ was reported to have an eco-physiological foundation (Vestergaard \& SandJensen 2000) because it controlled availability of carbon dioxide, membrane function, cell regulation and ion solubility for growth (Larcher 1995). In our study, maximum growth of $A$. pinnata along with the formation of dense mats (Table 2) was observed at $\mathrm{pH}$ ranging from 6.9 to 7.6 (Figure 1b). However Aziz \& Sharmin (2000) showed that pH 5 to 6 was favourable for the growth of this species under experimental conditions. Thus, transferring experimental observations to field situations is difficult and more field studies are warranted to elucidate favourable limnological conditions for the growth of a particular species.

Dissolved oxygen - Plant architecture and canopy formation have been reported to regulate dissolved oxygen concentration of the surrounding microenvironment (Miranda \& Hodyes 2000). They also reported a large variation in dissolved oxygen content $(0.5$ to $7.7 \mathrm{mg} \mathrm{l}^{-1}$ ) in densely vegetated areas with a mixture of submerged and emergent species. Dense mats of other free-floating plants namely Eichhornia crassipes and duckweeds have been reported to be poor oxyge- nators in tropical and temperate ponds respectively (Rai \& Dutta Munshi 1979, Lewis \& Bender 1961).

Electrical conductivity - Conductivity has been reported to be an important factor for explaining spatial distribution of aquatic plants (Seddon 1972, Kunii 1991). In the present study, a narrow band of this parameter could be associated with the dominance of $C$. glomerata (Figure 1d) which is similar to the observation of Biggs \& Price (1987). Since conductivity is affected by several electrolytes, which are variable independently, it would be interesting to study the concentration of different electrolytes for a better understanding of the occurrence pattern of this species. In temperate regions, nitrate concentration was reported to be closely associated with the vegetative growth of this species (Mason 1965).

Nutrients and Chlorophyll-a - A wide range of total Kjeldahl nitrogen and total phosphorus found for $V$. spiralis (Figure 1e \& $\mathrm{f}$ ) which is contrary to reports of a relatively low and narrow range of total Kjeldahl nitrogen and total phosphorus found in the same plant in a Canadian lake (Crowder et al. 1977). This may reflect the ability of $V$. spiralis to adapt itself to a wider range of nutrient concentration in tropical climates, where the amount of pollution is also high. Similar adaptability was also observed by Munawar (1970) in case of Eichhornia crassipes growing luxuriently in a tropical pond. Unlike V. spiralis, the presence of $L$. aequinoctialis was found to have a significant effect only on one water quality variable, namely total phosphorus (Figure 1f). The phosphorus uptake capacity of Lemna has been reported in tropical ponds (Tripathi et al. 1991) and being a free-floating plant, water possibly happens to be its sole source of phosphorus. Philipose et al (1970) also observed an association between the free-floating form specially Lemna and phosphorus rich water $\left(0.05\right.$ to $\left.3.6 \mathrm{mgl}^{-1}\right)$ in a survey of Indian water bodies including farm ponds. Dominance of floating-leaved species (Brasenia schreberi, Nymphoides cordata, Nymphaea odorata) was reported to be indicative of the eutrophic status of temperate ponds as a result of nutrient enrichment (Roman et al. 2001).

In tropical ponds, most plant species were found to grow when chlorophyll- $a$ levels were low $\left(\leq 12 \mathrm{mg} \mathrm{m}^{-}\right.$ 3 ), which could be due to competition for nutrients or allelopathic activities. In temperate ponds, low chlorophyll- $a$ concentration has been reported to be found near the densely vegetated areas of Charophytes (Noges et al. 2003), Elodea canadensis (Pokorny et al. 1984) under floating mats of Eichhornia crassipes (Mc Vea \& Boyd 1975) and near beds of Ceratophyllum demersum (Goulder 1969, Mjelde \& Faafeng 1997). 
It is interesting to note that all dominant plants showed their flexible requirements and competitive ability to adapt over a wide range of different water environments. On the other hand, it was the presence of minor flora which showed individual preference for specific range of some limnological variables like $E$. alba for low chlorophyll- $a$ concentration. In case of $T$. $n a-$ tans, the data reflects its multinutrient specificity i.e. its ability to grow in nitrogen enriched waters with low phosphorus levels. Net production of $T$. natans has also been reported to be positively correlated with nitrogen flux (Tsuchiya \& Iwakuma 1993). In a limnological survey of 149 Japanese ponds with Trapa as the dominant flora (56\% occurrence) low levels of total phosphorus concentration ( 0.003 to $0.241 \mathrm{mgl}^{-1}$ ) was also observed by Kunii (1991). Thus, the preference of low phosphorus level for this species is evident.

\section{Implications for pond management}

Users of ponds for anthropogenic purposes prefer transparent water (Secchi disk visibility $>0.5 \mathrm{~m}$ ) without algal turbidity. As can be seen in this study, the presence of most aquatic plants was associated with low algal turbidity while the presence of $M$. minuta, $N$. hydrophylla, V. spiralis and $R$. rotundifolia was associated with a wide range of water transparency. In another study, Mukhopadhyay et al (2004a) found that $V$. spiralis, a meadow forming submerged species exhibited the highest potential to maintain water clarity. The presence of invasive/canopy forming or free-floating vegetation, common to tropical ponds, generally block the water surface lower dissolved oxygen levels and also cause nuisance for swimming. The present study also threw some light on the favourable limnological conditions for the growth of two free-floating species namely Azolla pinnata and Lemna aequinoctialis, both of which are widely distributed throughout the world. Lemna, which grew luxuriantly at high phosphorus concencentrations was also present when chlorophyll$a$ concentrations were high. Knowledge of proper management of this species is necessary because removal of the aquatic plant often stimulate cyanobacterial blooms, which would lead to degradation of water quality. The potential of algal biomass to degrade water quality is reported to be highest in tropical latitude (Lewis, 2000) because in this climatic region pond ecosystems are about fifteen times more productive than their temperate counterparts (Bhaskaran et al. 1991). Native minor type/ low-growing species are more beneficial due to their low cost management (van Nes et al. 2002). They are probably capable of indicating useful limnological information due to their particular ecological preferences. Nutrient specificity of
Trapa could be used as an early warning of nitrogen/phosphorus enrichment and thus could be useful in nutrient management of tropical ponds. However, since the presence of minor species is probably more constrained by environmental factors, further research on a large number of macrophyte dominated ponds is necessary where these species are more common.

\section{Acknowledgements}

The help of Mr. L. Magranti and Mr. S. Sengupta during sample collection and water analysis and that of Mr. K. Sengupta for editing of the figures is greatfully acknowledged.

\section{References}

Angélibert S., Marty P., Céréghino R. \& Giani N. 2004. - Seasonal variations in the physical and chemical characteristics of ponds : implications for biodiversity conservation. Aquatic Conserv : Mar. Freshw. Ecosyst., 14, 439-456.

APHA 1998. - Standard methods for the examination of water and wastewater. 20 th $\mathrm{ed}$, American Public Health Association, New York, 10-161 p.

Aziz A. \& Sharmin S. 2000. - Growth and nitrogenease activity of Azolla pinnata var. pinnata $\mathrm{R}$. Brown as affected by some environmental factors. Bangladesh J. Bot., 29, 125-131.

Baldwin M.F. 1991. - Natural resources of Sri Lanka : conditions and trends. Natural Resources, Energy and Science Authority of Sri Lanka, Colombo.

Bhaskaran R., Nambtraian V.S. \& Alaguchamy N. 1991. - Phytoplankton productivity in a few tropical ponds. J. Ecobio., 3, 275284.

Biggs B.J.F. \& Price G.M. 1987. - A survey of filamentous algal proliferation in New Zealand rivers. N. Z. J. Mar. Freshwat. Res., 21, 175-192.

Catling P.M., Freedman B., Stewart C., Kerekes J.J. \& Lefkovitch L.P. 1986. - Aquatic plants of acidic lakes in Kejimkujik National Park, Nova Scotia : floristic composition and relation to water chemistry. Can. J. Bot., 64, 724-729.

Cook C.D.K. 1996. - Aquatic and Wetland Plants in India. Oxford University Press, Oxford. 385 p.

Crawford S.A. 1977. - Chemical, physical and biological changes associated with Chara succession in farm ponds. Hydrobiologia, $55,209-217$.

Crowder A.A., Bristow J.M. \& King M.R. 1977. - Distribution, seasonality and biomass of aquatic macrophytes in Lake Opinicon (eastern Ontario). Nat. Can., 104, 441-456.

Dennis W.M. \& Isom B.G. 1984. - Ecological assessment of macrophyton : collection, use and meaning of data. ASTM STP 843 , American Society for Testing and Materials, Philadelphia, $122 \mathrm{p}$.

Dixon W.J. 1992. - BMDP statistical software manual. University of California Press, Berkeley, 1500 p.

Friday L.E. 1987. - The diversity of macroinvertibrate and macrophyte communities in ponds. Freshwat. Biol., 18, 87-104.

FRSS 1986. - Water area statistics of Bangladesh. Govt of Bangladesh, Dhaka. Fish Information Bulletin, 3, 1-3.

Ghosh S.K. 2005. - Illustrated Aquatic and Wetland Plants in Harmony with Mankind. Standard Literature, India, $225 \mathrm{p}$.

Ghosh S.K., Santra S.C. \& Mukherjee P.K. 1993. - Phenological studies in aquatic macrophytic plants of lower Gangetic delta, West Bengal, India. Feddes Repertorium, 104, 93-111.

Gichuki J., Dahdouh Guebas F., Mugo J., Rabuor C.O., Triest L. \& Dehairs F. 2001. - Species inventory and the local uses of the 
plants and fishes of the Lower Sondu Miriu wetland of Lake Victoria, Kenya. Hydrobiologia, 458, 99-106.

GOI 2005. - Water Resoueces in India. Ministry of Water Resources, Govt. of India, New Delhi. http://wrmin.nic.in

Gopal, B. 1990. - Ecology and management of aquatic vegetation in the Indian Subcontinent. Kluwer Academic Publishers, Dordrecht. $257 \mathrm{p}$.

Gopal B. \& Chamanlal 1991. - Distribution of aquatic macrophytes in polluted water bodies and their bioindicator value. Verh. Intrenat. Verein. Limnol., 24, 2125-2129.

Goulder R. 1969. - Interactions between the rates of production of a freshwater macrophyte and phytoplankton in a pond. Oikos, 20, 300-309.

Heegaard E., Birks H.H., Gibson C.E., Smith S.J. \& Wolfe-Murphy S. 2001. - Species-environmental relationships of aquatic macrophytes in Northern Ireland. Aquat. Bot., 70, 175-223.

Hussainy S.U. 1965. - Limnological studies of the departmental pond at Annamalai nagar. Environmental Health, 12, 24-31.

Hutchinson G.E. 1975. - A treatise on Limnology III Limnological Botany. Wiley, New York, $660 \mathrm{p}$

James C., Fisher J., Russeli V., Collings S. \& Moss B. 2005. - Nitrate availability and hydrophyte species richness in shallow lakes. Freshwat. Biol., 50, 1049-1063.

Jana B.B. \& Kundu G. 1993. - Influence of prolonged summer on the limnology and chlorophyll- $a$ content of phytoplankton in two tropical fish ponds. Arch. Hydrobiol. (suppl.), 90, 507-532.

Kadono Y. 1982. - Occurrence of aquatic macrophytes in relation to $\mathrm{pH}$, alkalinity, $\mathrm{Ca}^{++}, \mathrm{Cl}^{-}$and conductivity. Japanese J. Ecol., 32 $39-44$

Khondker M. \& Kabir Md. A. 1995. - Phytoplankton primary production in a mesotrophic pond in sub-tropical Bangladesh. $H y$ drobiologia, 304, 39-47.

Kunii H. \& Maeda K. 1982. - Seasonal changes in surface cover of aquatic plants in a shallow pond, Ojaga-ike, Chiba, Japan. Hydrobiologia, 37, 45-55.

Kunii H. 1991. - Aquatic macrophyte composition in relation to environmental factors of irrigation ponds around Lake Shinji, Shimane, Japan. Hydrobiologia 97, 137-148.

Larcher W. 1995. - Physiological Plant Ecology. Springer-Verlag, NewYork, 506 p.

Lewis Jr W.M. 2000. - Basis for the protection and management of tropical lakes. Lake Reserv. : Res. Mgmt., 5, 35-48.

Lewis W.M. \& Bender M. 1961. - Effect of a cover of duckweed and the alga Pithophora upon the dissolved oxygen and free carbon dioxide in small ponds. Ecology, 42, 602-603.

López-Blanco J. \& Zambrano L. 2002. - Characterization of small ponds with colour video imagery in Central Mexico. Hydrobiologia, 67, 177-185.

Mäkelä S., Huitu E. \& Arvola L. 2004. - Spatial patterns in aquatic vegetation composition and environmental covarites along chain of lakes in the Kokemäenjoki watershed (S. Finland). Aquat. Bot., 80, 253-269.

Mason C.P. 1965 - Ecology of Cladophora in farm ponds. Ecology, 46, 421-429.

Mc Vea C. \& Boyd C.E. 1975. - Effects of water hyacinth cover on water chemistry, phytoplankton and fish in ponds. J. Environ. Qual., 4, 375-378.

Miranda L.E. \& Hodyes K.B. 2000. - Role of aquatic vegetation coverage on hypoxia and sunfish abundance in bays of a eutrophic reservoir. Hydrobiologia, 427, 51-57.

Mjelde M. \& Faafeng B.A. 1997. - Ceratophyllum demersum hampers phytoplankton development in some small Norwegian lakes over a wide range of phosphorus concentrations and geographica latitude. Freshwat. Biol. 37, 355-365.
Moyle J.B. 1945. - Some chemical factors influencing the distribution of aquatic plants in Minnesota. Am. Midl. Nat., 34, 402-420.

Mukhopadhyay G. \& Dewanji A. 2002. - Studies on the seasonal variation of water quality parameters and macrophyte coverage in a pond. Asian J. Microbiol. Biotech. Environ. Sci., 4, 165-169.

Mukhopadhyay G. \& Dewanji A. 2004a. - The ability of aquatic macrophytes to maintain water clarity in two tropical ponds. Internat. J. Environ. Stu., 61, 579-586.

Mukhopadhyay G., Mondal D., Biswas P. \& Dewanji A. 2004b. Water quality monitoring of tropical ponds : location and depth effect in two case studies. Acta Hydrochim. Hydrobiol., 32, 138148

Munawar M. 1970. - Limnological studies on freshwater ponds at Hyderabad, India. II. The Biocenose. Distribution of unicellular and colonial phytoplankton in the polluted and the unpolluted enviroments. Hydrobiologia, 36, 105-128.

Nasar S.A.K. \& Datta Munshi J. 1974. - Seasonal variations in the physico-chemical and biological properties of a tropical shallow pond. Jap. J. Ecol., 24, 255-259.

Noges P., Tuvikene L., Feldmann T., Tonno I., Kunnap H., Luup H., Salujoe J. \& Noges T. 2003. - The role of charophytes in increasing transparency: a case study of two shallow lakes in Estonia. Hydrobiologia, 506-509, 567-573.

Palmer M.A., Bell S.L. \& Butterfield I. 1992. - A botanical classification of standing waters in Britain : applications for conservation and monitoring. Aquatic Conserv : Mar. Freshw. Ecosyst. 2, 125 143

Pandey S., Dudani V.K. \& Kumar S. 1988. - Limnochemistry of a hyper-eutrophic fish pond (Harahi) of Darbhanga. Pages 257- 267 in Environmental pollution and its impact on the level of organism in the society. Trivedi, R.N. (ed). Bharati Bhawan, India.

Philipose M.T., Ramachandran V., Singh S.B. \& Ramaprabhu T. 1970. - Some observations on the weeds of cultivable freshwaters in Orissa. J. Inland Fish. Soc. 11: 61-84.

Pokorny J., Kevt J., Ondok J.P., Toul Z. \& Ostry I. 1984. - Production-ecological analysis of a plant community dominated by Elodea canadensis. Aquat. Bot., 19, 263-292.

Rai D.N. \& Dutta Munshi J. 1979. - The influence of thich floating vegetation (water hyacinth : Eichhornia crassipes) on the physico-chemical environment of a freshwater wetland. Hydrobiologia, 62, 65-69.

Roman C.T., Barrett N.E. \& Portnoy J.W. 2001. - Aquatic vegetation and trophic status of Cape Cod (Massachusetts, U.S.A.) Kettle ponds. Hydrobiologia, 443, 31-42.

Schneider S. \& Melzer A. 2003. - The trophic index of macrophytes (TMI)-a new tool for indicating the trophic status of running waters. Internat. Rev. Hydrobiol., 88, 49-67.

Seddon B. 1972. - Aquatic macrophytes as limnological indicators. Freshwat. Biol., 2, 107-130.

Shimoda M. \& Abe H. 2001. - Irrigation pond ecosystem and its changes-waters of rich biodiversity in rural landscape. Proceedings of $9^{\text {th }}$ International Conference on the conservation and management of lakes. Biwako, Japan, 285-288 p.

Spence D. H. N. 1967. - Factors controlling the distribution of freshwater macrophytes with particular reference to the lochs of Scotland. J. Ecol., 55, 147-170.

Steinman A.D., Havens K.E., Rodusky A.J., Sharfstein B., James T. \& Harwell M.C. 2002. - The influence of environmental variables and a managed water recession on the growth of charophytes in a large, subtropical lake. Aquat. Bot., 72, 297-313.

Tripathi B.D., Srivastava J. \& Misra K. 1991. - Nitrogen and phosphorus removal capacity of four chosen aquatic macrophytes in tropical freshwater ponds. Environ. Conserv., 18, 143-147. 
Tsuchiya T. \& Iwakuma T. 1993. - Growth and leaf life-span of a floating leaved plant, Trapa natans L., as influenced by nitrogen flux. Aquat. Bot., 46, 317-324.

van Nes E.H., Schffer M., van den Berg M.S. \& Coops H. 2002. Aquatic macrophytes : restore, eradication or is there a compromise ? Aquat. Bot., 72, 387-403.

Varshney C.K. \& Singh K.P. 1976. - A survey of aquatic weed problem in India. Pages 31-41 in Aquatic weeds in south east Asia. Varshney, C.K. \& Rzóska, J (eds). Dr. W. Junk Publishers, The Hague.

Vestergaard O. \& Sand-Jensen K. 2000. - Alkalinity and trophic state regulate aquatic plant distribution in Danish lakes. Aquat. Bot.,
67, 85-107.

Welch P.S. 1952. - Limnology. 2nd ed, Mc Graw-Hill, New York. $538 \mathrm{p}$

Whitton B.A. 1979. - Plants as indicators of river water quality. Pages 5.1-5.34 in Biological indicators of water quality. James A. \& Evinson L. (eds). John Wiley and Sons, New York.

Xiangcan J. 2003. - Analysis of eutrophication state and trend for lakes in China. J. Limnol., 62, 60-66.

Zambrano L., Perrow M.R., Macias-Garcia C. \& Aguirre-Hidalgo V. 1999. - Impact of induced carp (Cyprinus carpio) in subtropical shallow ponds in Central Mexico. J. Aquat. Ecosyst. Stress and Recovery, 6, 281-288. 